OPEN ACCESS

Edited by:

Les Watling,

University of Hawai'i at Mānoa

United States

Reviewed by:

Natalya D. Gallo,

University of Bergen, Norway

Susumu Ohtsuka,

Hiroshima University, Japan

*Correspondence:

Magnus Drivdal

magnus.drivda/@akvaplan.niva.no

Specialty section:

This article was submitted to

Marine Biology,

a section of the journal

Frontiers in Marine Science

Received: 08 September 2021 Accepted: 26 November 2021 Published: 15 December 2021

Citation:

Drivdal M, Kunisch EH, Bluhm BA, Gradinger R, Falk-Petersen S and Berge J (2021) Connections to the Deep: Deep Vertical Migrations, an Important Part of the Life Cycle of Apherusa glacialis, an Arctic Ice-Associated Amphipod.

Front. Mar. Sci. 8:772766. doi: 10.3389/fmars.2021.772766

\section{Connections to the Deep: Deep Vertical Migrations, an Important Part of the Life Cycle of Apherusa glacialis, an Arctic Ice-Associated Amphipod}

\author{
Magnus Drivdal'1*, Erin H. Kunisch², Bodil A. Bluhm², Rolf Gradinger², \\ Stig Falk-Petersen ${ }^{1}$ and Jørgen Berge $\mathbf{e}^{2,3,4}$
}

\begin{abstract}
${ }^{1}$ Akvaplan-Niva, Fram Centre, Tromsø, Norway, ${ }^{2}$ Department of Arctic and Marine Biology, Faculty of Biosciences, Fisheries and Economics, UiT The Arctic University of Norway, Tromsø, Norway, ${ }^{3}$ Department of Arctic Biology, The University Centre in Svalbard (UNIS), Svalbard, Norway, ${ }^{4}$ NTNU Centre for Autonomous Marine Operations and Systems, Marine Technology Centre, Trondheim, Norway
\end{abstract}

Arctic sea ice contains a substantial amount of living biota of which part is lost through melt and export out of the Arctic Ocean every year. It is unclear how populations can be maintained within the Arctic Ocean. A representative ice inhabitant, the amphipod Apherusa glacialis was previously assumed to spend its entire life in the sea ice habitat, hence being dependent on sea ice to complete its life cycle. However, several recent studies report pelagic occurrences and suggest that seasonal vertical migrations might be an adaptive life history trait enabling a viable population size in the Arctic Ocean. In this study we use a particle-tracking model to investigate to what extent vertical migration might affect the species' retention in the Arctic Ocean and the sea ice habitat. The modeled trajectories of $A$. glacialis were calculated based on ice drift and ocean currents from a coupled ocean - sea ice model covering the Arctic Ocean. We test two scenarios: (1) trajectories of $A$. glacialis that stay attached to the ice or follow the surface currents if they melt out of the ice and (2) trajectories of $A$. glacialis that undertake a seasonal vertical migration to drift with the currents at depth for parts of the year. In the multi-year model simulations it is assumed that after an initial period of 2 years $A$. glacialis that are located outside sea-ice cover each spring will perish while those located within the ice-covered region will reproduce. The model results show that a seasonal vertical migration both increases the total number of individuals and leads to a population distribution within the Arctic Ocean more in line with previous findings than the results from the non-migrating $A$. glacialis. Our results support the hypothesis that a seasonal migration may be an adaptive life history strategy in this species.

Keywords: amphipod, Arctic, sea ice, life cycle, particle tracking, vertical migration, Apherusa glacialis 


\section{INTRODUCTION}

In general, the Arctic pelagic marine ecosystem contains very few endemic species, mostly due to the absence of barriers and isolation between the Arctic Ocean and its surrounding seas. Rather, strong biogeographic connections and interchange of water masses with the North Atlantic sub-Arctic seas, and to a lesser extent with the North Pacific are characteristic features. Yet, Arctic sea ice provides a unique habitat absent from subArctic seas, with a high biodiversity including a number of endemic species [examples in Bluhm et al. (2011)]. More than 1,000 species, ranging from unicellular bacteria and algae up to larger crustaceans, mammals and sea birds are known to live on, in, or in close connection to the sea ice during at least parts of their life cycle (Poulin et al., 2011; Bluhm et al., 2017). The ice habitat also serves as platform for breeding seals (Laidre et al., 2008; Kovacs et al., 2011), as protective habitat from predators for young polar cod (Gradinger and Bluhm, 2004), as feeding habitat for metazoan meiofauna in the brine channel systems (Gradinger and Bluhm, 2020) and the underside as habitat for e.g., sea ice associated algae and amphipods and for pelagic flora and fauna such as various copepods, amphipods, comb jellies, etc. (Ehrlich et al., 2020). Questions remain on how the sea ice taxa, which mainly drift passively with ice and currents, can maintain their populations within the Arctic Ocean when sea ice is continuously exported from the Arctic.

The ice-cover and its drift are closely related to Arctic Ocean hydrography and circulation. The Arctic Ocean is a semi-enclosed ice-covered ocean, with extensive shelves and a deep basin with maximum depths of more than $4,000 \mathrm{~m}$, as first described by Nansen (1902). The main large-scale winddriven surface circulation and sea ice drift features of the Arctic Ocean are the Beaufort Gyre and the Transpolar Drift (Figure 1). The fundamental features and current systems of the Norwegian Sea including the Greenland-Iceland-Norwegian (GIN) Seas and the connection to the Arctic Ocean were later described by Helland-Hansen and Nansen mainly based on the data collected between 1900 and 1904 (Helland-Hansen and Nansen, 1909). A prominent feature of this circulation is the inflow of warm surface water from the North Atlantic that submerges under colder Arctic water when entering the Arctic, and continues to flow through the Arctic and along the pan-Arctic slope; modified Atlantic water in fact fills all deep Arctic basins (Rudels et al., 2000, 2013; Figure 1). Our knowledge of these interconnected systems has been updated and documented in several fundamental studies (Hansen and Østerhus, 2000; Rachold et al., 2004; Falk-Petersen et al., 2007; Rudels, 2015; Semper et al., 2020; Wassmann et al., 2020). The ocean current system (Figure 1) provides exchange of water, particulate matter, phytoplankton, zooplankton, ice biota and other matter including sediments from the Siberian shelf and rivers, between the North Atlantic and the Arctic (Timmermans and Marshall, 2020; Daase et al., 2021). Connectivity to the Pacific is limited to northward inflow into the Arctic through the shallow Bering Strait (Woodgate et al., 2005). Sea ice is a unique feature of the Arctic Ocean, consisting of drifting pack ice and land fixed fast ice. Approximately $50 \%$ of the ice cover has been seasonally melting in the past, leaving the central Arctic ice covered yearround by multi-year ice floes, yet with less and less multi-year ice remaining in recent decades. Both annual and perennial sea ice formed inside the Arctic are exported out following the surface currents and prevailing winds, with the major export happening through western Fram Strait. This transport accounts for an estimated average export of $14 \%$ of the sea ice volume every year, and has a strong seasonality, with most of the export happening in the winter months from November to April (Spreen et al., 2020).

Historically, organisms living in or on the underside of the sea ice habitat were classified into two groups: the allochthonous and autochthonous ice-associated species. The former group consists of species that spend parts of their life cycle in connection to the sea ice, the latter classified organisms that were assumed to be fully dependent on sea ice throughout their life cycle. In terms of sea ice fauna biomass, the latter group is dominated by crustacean amphipods (Lønne and Gulliksen, 1991a,b) originally with four species (Gammarus wilkitzkii, Apherusa glacialis, Onisimus nanseni, and Onisimus glacialis), later expanded to also include Pleusymtes karstensi (Macnaughton et al., 2007). Since their association with sea ice has been considered obligatory, these organisms would lose both their sea ice habitat during ice melt and be advected out of the Arctic Ocean by the Transpolar Drift (Gulliksen and Lønne, 1991; Lønne and Gulliksen, 1991b; Arndt and Swadling, 2006). When the sea ice melts, these organisms are subjected to horizontal transport in the water column by ocean currents. Unless they can remain in an area where ice forms in the subsequent winter or they are transported back into the ice within their lifespan, these organisms are inevitably lost from the population. Several studies have investigated the biomass transport of ice biota into the Greenland and Barents Seas and estimated it to be on the order of $3.55^{*} 10^{6} \mathrm{t}$ wet weight $\left(4.2^{*} 10^{5} \mathrm{tC}\right)$ year $^{-1}$ and $1.5^{*} 10^{5} \mathrm{t}$ wet weight $\left(1.8^{*} 10^{4} \mathrm{tC}\right)$ year $^{-1}$, respectively (Hop et al., 2006; Wassmann et al., 2006). These calculations and estimates, however, are based on the general assumption that the organisms in question are truly dependent on sea ice for their survival.

For A. glacialis (Figure 2), the most abundant of the five assumed obligate ice-associated amphipod species, the obligatory sea ice association may be less strong than assumed. It had been originally considered a pelagic species (Barnard, 1959), but extensive and regular findings of the species living on the underside of the Arctic drift ice changed the general understanding of its ecology to that of an autochthonous ice associated herbivorous species (Scott et al., 1999; Beuchel and Lønne, 2002; Werner and Auel, 2005). Recently, however, Berge et al. (2012) and Kunisch et al. (2020) have questioned the obligate nature of the ice association for this species. Based on findings of A. glacialis in the deep layers of inflowing Atlantic water into the Arctic Ocean, Berge et al. (2012) suggested a conceptual model in which deep migration was an integrated part of A. glacialis' 2-year life cycle (Poltermann et al., 2000; Beuchel and Lønne, 2002) in at least parts of the Arctic. It was suggested that A. glacialis grazes on ice algae during the productive spring, summer and autumn as the sea ice drifts south into the Greenland Sea, then migrates down to depths following the current system across the Norwegian Sea and re-enters the Arctic Ocean via the 


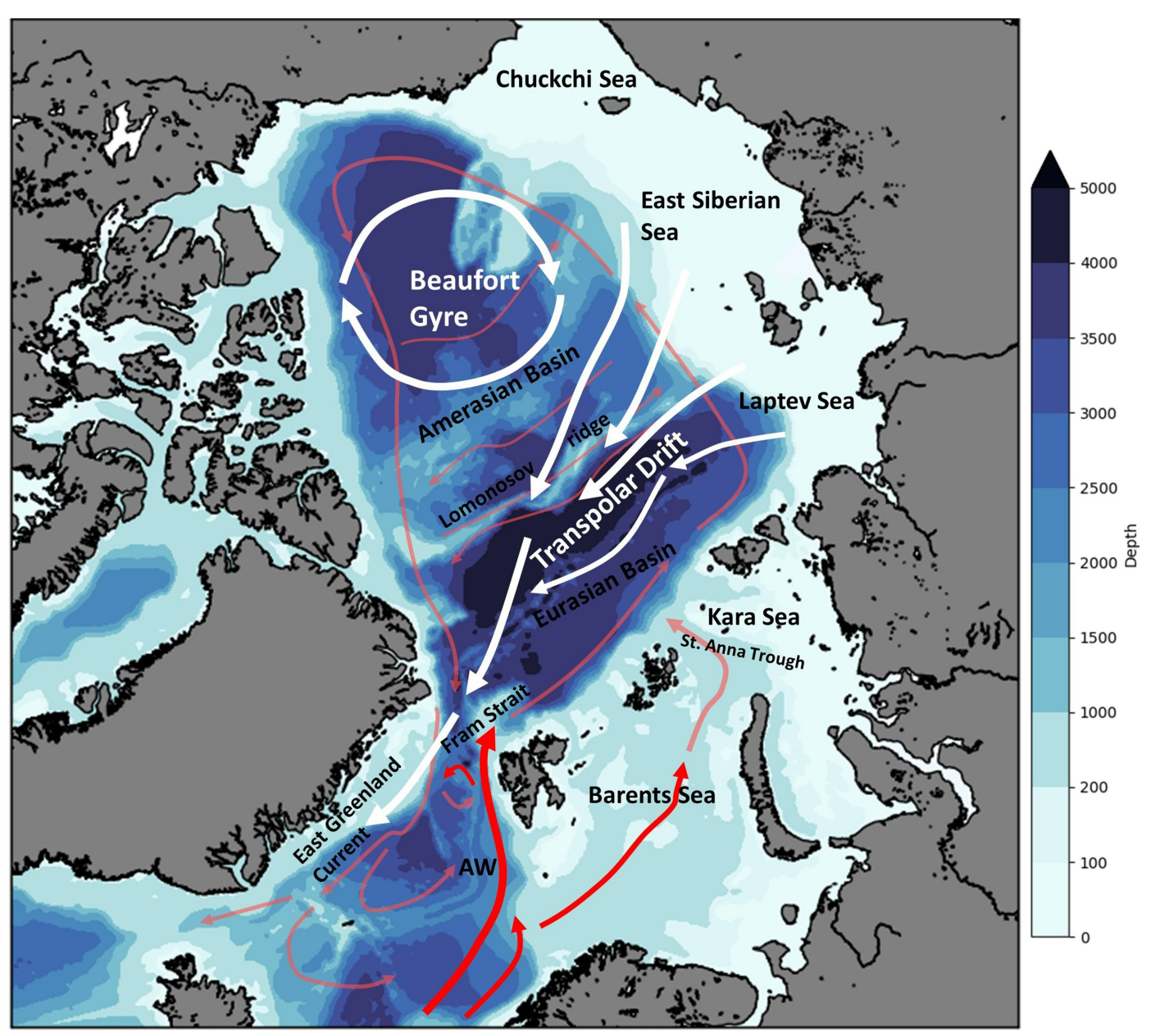

FIGURE 1 | Schematic of major current features in the Arctic Ocean and North Atlantic. The colored contours indicate the bathymetry (from the ETOPO1 global bathymetry model, scale bar: depth in $\mathrm{m}$ ). Atlantic water (AW, red lines) enters the Arctic Ocean through the Fram Strait and via a separate branch through the Barents/Kara Seas, then circulates the Arctic Basin as a subsurface current (light red). The Beaufort Gyre and the Transpolar Drift are surface features (indicated by white arrows) that influence sea ice drift patterns. The Lomonosov Ridge divides the Arctic Basin into the Amerasian Basin and the Eurasian Basin. Pacific Water inflow is omitted (doi: 10.7289/N5C8276M).

north flowing Atlantic Current. Kunisch et al. (2020) conducted an extensive review of all reported pelagic findings of A. glacialis in the Arctic and concluded that it was regularly found in the water column throughout the year.

In this study we examine a hypothesis based on the findings by Berge et al. (2012) and Kunisch et al. (2020), namely that deep vertical migration after grazing on the ice-algal bloom would enhance the return and retention of A. glacialis in the Arctic Ocean. This can occur in summer and until the polar night. Such deep migration may enhance their fitness by both avoiding predation at a time when they carry young in a large brood pouch, and secondly by allowing them to relocate themselves either within or even back into the Arctic Ocean by advection as proposed by Berge et al. (2012). To test the advective component of the hypothesis, we use a particle trajectory model. We consider two parallel model scenarios where initially A. glacialis (as seeded particles) are located in identical areas covering large parts of the ice-covered Arctic Ocean. The amphipods in the two scenario populations follow the same strategy for the periods when sea ice-based food is available, staying attached to the ice (if ice is available) or close to the ocean surface. For the rest of the year the two populations behave differently, with amphipods in one migrating downwards to the core of the relatively warm Atlantic layer (here chosen at a depth of about 250 m; Lind et al., 2016; Bluhm et al., 2020), while in the other they remain attached to the ice (if available) or otherwise in the surface water layer.

\section{MODEL SETUP AND METHODS}

The coupled ocean-sea ice model used in this study is a $4 \mathrm{~km}$ panArctic setup (Arctic-4) of the Regional Ocean Modeling System (ROMS, Shchepetkin and McWilliams, 2005) with a coupled sea-ice component (Budgell, 2005). For Arctic-4 the initial hydrodynamic fields and boundary conditions are provided by a monthly global ocean reanalysis (Storkey et al., 2010); surface 


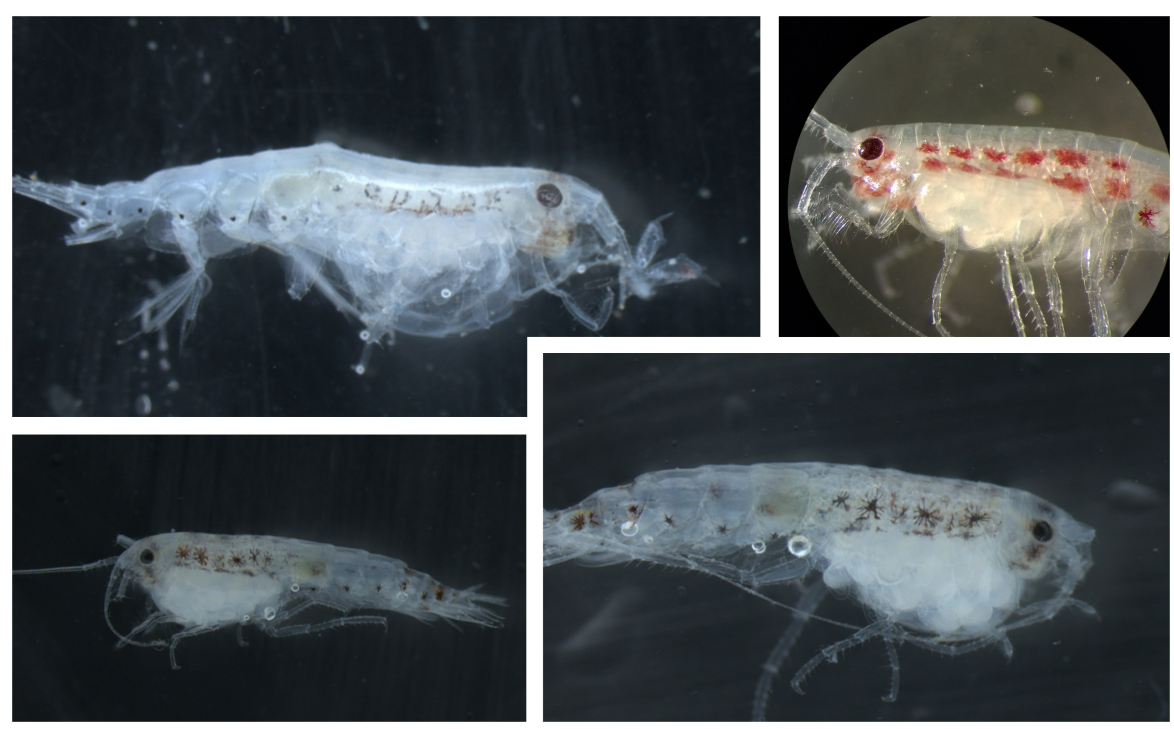

FIGURE 2 | Four examples of egg carrying female A. glacialis collected in the water column in January 2017 North of Svalbard. All specimens were collected by plankton nets below $200 \mathrm{~m}$. Note that all specimens carry large and relatively few eggs, in contrast to what has been reported previously (Poltermann, 2000). Adult females most commonly have body sizes between 9 and 12 mm, but can range from 7 to 16 mm (Poltermann et al., 2000; Kunisch et al., 2020).

atmospheric forcing fields, such as near-surface wind, sea-level pressure and temperature are provided by a global atmospheric reanalysis (ERA-Interim: Dee et al., 2011). Tidal forcing is added at the open ocean boundaries from the tidal model TPXO (Egbert and Erofeeva, 2002). The Arctic-4 model has previously been run from 1993, with the 10 first years acting as a spin-up from ice-free conditions. Here the ocean current and ice drift from these simulations have been used as input for a separate particle tracking model. A more detailed description of the Arctic-4 model can be found in Hattermann et al. (2016). In the present study the particle (amphipod) trajectories were calculated from the Arctic-4 model fields from the years 2008-2017. The currents and ice drift from Arctic- 4 respond to the continuously shifting atmospheric and boundary forcing conditions. Prevailing atmospheric conditions and current patterns may lead to significant year to year variations in ice cover and drift patterns, which again lead to annual variations in particle distribution and transport in and out of the Arctic Ocean.

Trajectories of the modeled A. glacialis were computed with TRACMASS (Döös et al., 2013, 2017) forced by the daily averaged model velocities from the Arctic-4 model. By using the daily averages, high frequency variability such as tides were filtered out. To simulate the trajectories of the particles in the ice, the model forcing was modified so that particles at the surface follow ice-velocities, which are largely forced by the wind (e.g., Spreen et al., 2011), if the ice cover in the region is above $10 \%$. Otherwise, the particles follow the water masses transported by the ocean currents. This $10 \%$ threshold for ice drift to replace surface current drift is slightly lower than the $15 \%$ often used to describe the sea ice extent (e.g., Stroeve et al., 2012), ${ }^{1}$ but was chosen as we assumed $A$. glacialis to have a high preference

${ }^{1}$ https://earth.gsfc.nasa.gov/cryo/data/current-state- sea-ice- cover to stay in the ice when food is available, even at low sea ice concentrations. To model vertical migration, the model was run according to a specific procedure, where particles were removed and subsequently reseeded at different depths. This simplified procedure assumes that the migration itself is a short process and the drift patterns during the vertical migration itself were not considered. The dominating ocean circulation patterns and associated sea ice drift are sketched in Figure $\mathbf{1}$. However, there are temporal fluctuations in the current and icedrift due to changing weather patterns that can influence the particle transport in the model. For example, the Norwegian Atlantic Current can be $\sim 20 \%$ stronger in its mean flow in winter (Andersson et al., 2011), and wind forcing accounts for a large fraction of the variation of summer-fall sea ice extent in the Arctic (Ogi et al., 2010). Yet in the present study our focus is on the broad-scale differences in amphipod distributions with and without vertical migrations, recognizing that absolute magnitudes will differ between years.

With the applied setup, the trajectories could be followed both as particles leave and re-entered the ice-covered regions. In the experiments, a large sector of the Arctic was seeded with approximately 350,000 particles (Figure 3) on 1 April 2008, and the individual trajectories were followed for several years (first for the period 2008-2013, and then in a separate run for 2008-2017). For modeling purposes, the yearly cycle of A. glacialis was split into two periods: the biologically active season (approximately when A. glacialis are assumed to be feeding on fresh algal material and algal detritus at/near the sea ice; Scott et al., 1999; Poltermann, 2001) 1 April - 31 July, and the biologically passive period 1 August - 31 March (little primary production (Leu et al., 2015), with little or no feeding). The trajectory model was first run for 2 years for two different scenarios: one with no vertical migration, and the other with seasonal migration as was proposed 

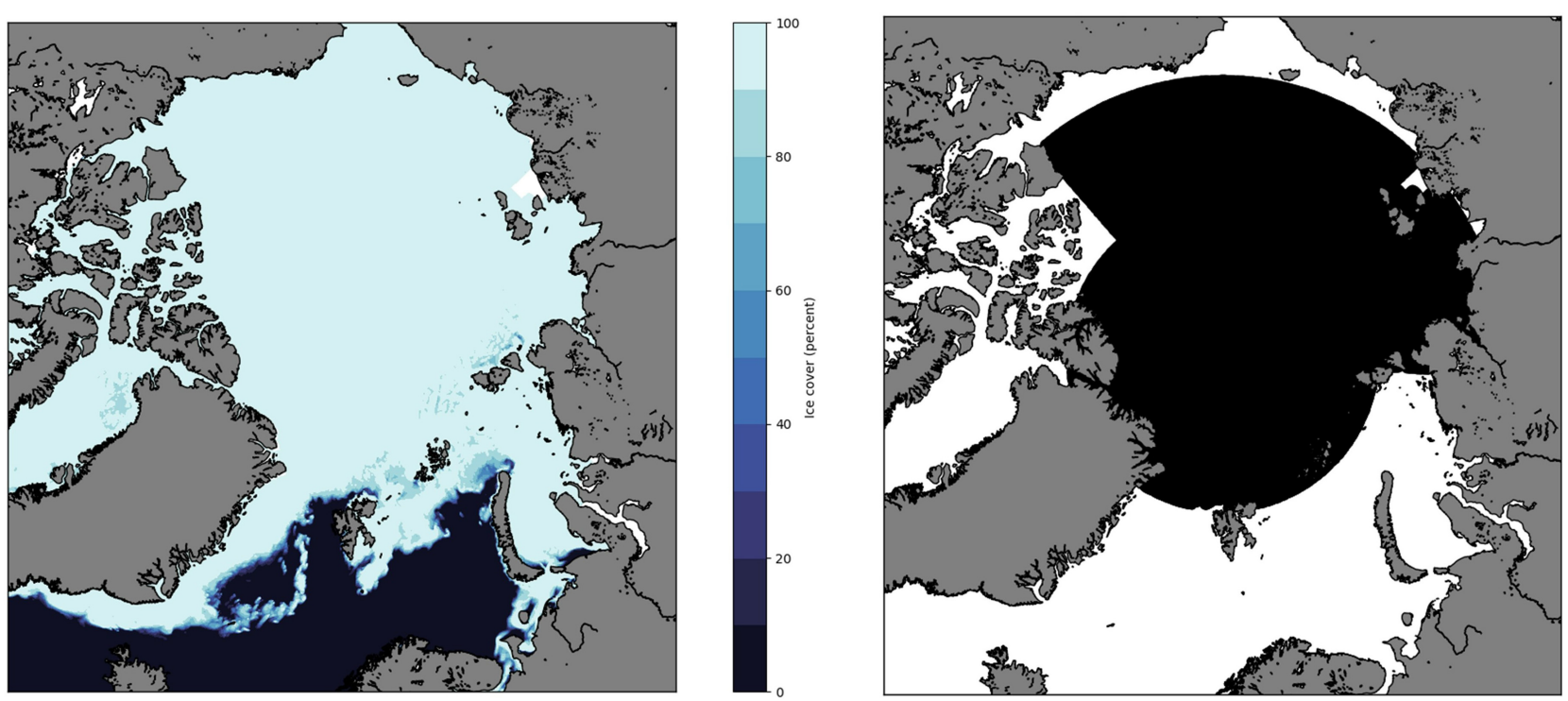

FIGURE 3 | lce cover in Arctic-4 1 April 2008 (left) and initial particle seeding sector in black (right). The color scale (left hand side) shows sea ice cover in percent.

by Berge et al. (2012). For the non-migrating scenario, we allowed A. glacialis to follow the ice drift if located in an area with ice cover greater than or equal to $10 \%$. In contrast, $A$. glacialis was allowed to drift with the surface current when they reached areas with less ice cover $(<10 \%)$. For the migrating scenario, A. glacialis had the same behavior in the active period (1 April - 31 July) but migrated down to $250 \mathrm{~m}$ (or the sea bottom if shallower) and followed the ocean currents passively at that depth for the period 1 August - 31 March before they migrated back up to the surface every 1 April. The water depth of $250 \mathrm{~m}$ was chosen because it is a reasonable approximation of the Atlantic layer core in the study area where temperatures are above $0^{\circ} \mathrm{C}$ (and even warmer in the Atlantic inflow area of the Fram Strait and Barents Sea) and salinity is at 34.8-35.0 (Loeng, 1991; Lind and Ingvaldsen, 2012; Bluhm et al., 2020) and current velocities northward can reach upward of $15 \mathrm{~cm} \mathrm{~s}^{-1}$ (Aksenov et al., 2011; Menze et al., 2019). For simplicity, vertical migration in the model was assumed to occur at the same time every year for all individuals. The choice of timing of the arrival after migration up to the sea ice is based on the observation of the predominance of small size classes in the sea ice habitat in spring months (Melnikov, 1997; Kunisch et al., 2020). The timing of migration to depth is inferred from observations of mating during early winter, the finding of gravid females in deeper water layers, and the virtual absence of gravid females in surface layers from spring to fall (Melnikov, 1997; Poltermann et al., 2000; Berge et al., 2012; Kunisch et al., 2020). The vertically migrating particles thus avoid following the ice drift during the winter months, when the major sea-ice transport through the Fram Strait occurs (Spreen et al., 2020). Although the sea ice transport may vary from year to year, this behavior was expected to lead to a significant reduction in the transport of particles from the Arctic to the GIN seas.

For practical reasons the representation of mortality and reproduction in the particle tracking model was simplified. From the start of the simulation, 1 April 2008 until 1 April 2010, the number of particles representing $A$. glacialis was kept constant (unless they exited the model domain). Subsequently, starting in 2010 and each 1 April from then on, all particles were counted and split into two groups: group one included those remaining or having re-entered the ice-covered region (defined as greater than or equal to $10 \%$ ice cover) and group two included those located in the open ocean. The model was then reseeded with 2 particles for each particle in group one (representing reproduction) and run forwards until next 1 April. The particles in group two were removed and accounted for mortality/population loss every year. This procedure was used to represent a simplified life cycle with mortality and reproduction, where an average of two offspring survived each year (for particles in the sea ice). With this simplistic 1:2 reproduction rate there was population growth for both scenarios (migrating and non-migrating) and the number of particles became impractical for the model to handle after 5 years (2013). In addition, we assumed that individuals may survive in the water column during the entire winter period but die if they are located in a totally ice-free area the following 1 April. Hence, the modeled A. glacialis may leave the sea-ice after 1 April and still be able to survive and reproduce later if they re-enter the sea-ice habitat before 1 April the following year. During such a pelagic stage, one possible return-route to the sea-ice habitat for the migrating particles could be to follow the Atlantic Current northwards, as proposed by Berge et al. (2012).

To analyze general longer-term distribution patterns and inter-annual variability, a separate run was performed for both scenarios until 2017, only accounting for mortality (using a 1:1 reproduction rate for individual particles in sea-ice). The reason for using a 1:1 reproductive rate in this model run is a practical one, namely that the model could not handle the population growth with the previously used 1:2 rate in the long term. These simulations diverge from the first ones from 2010. For each 1 

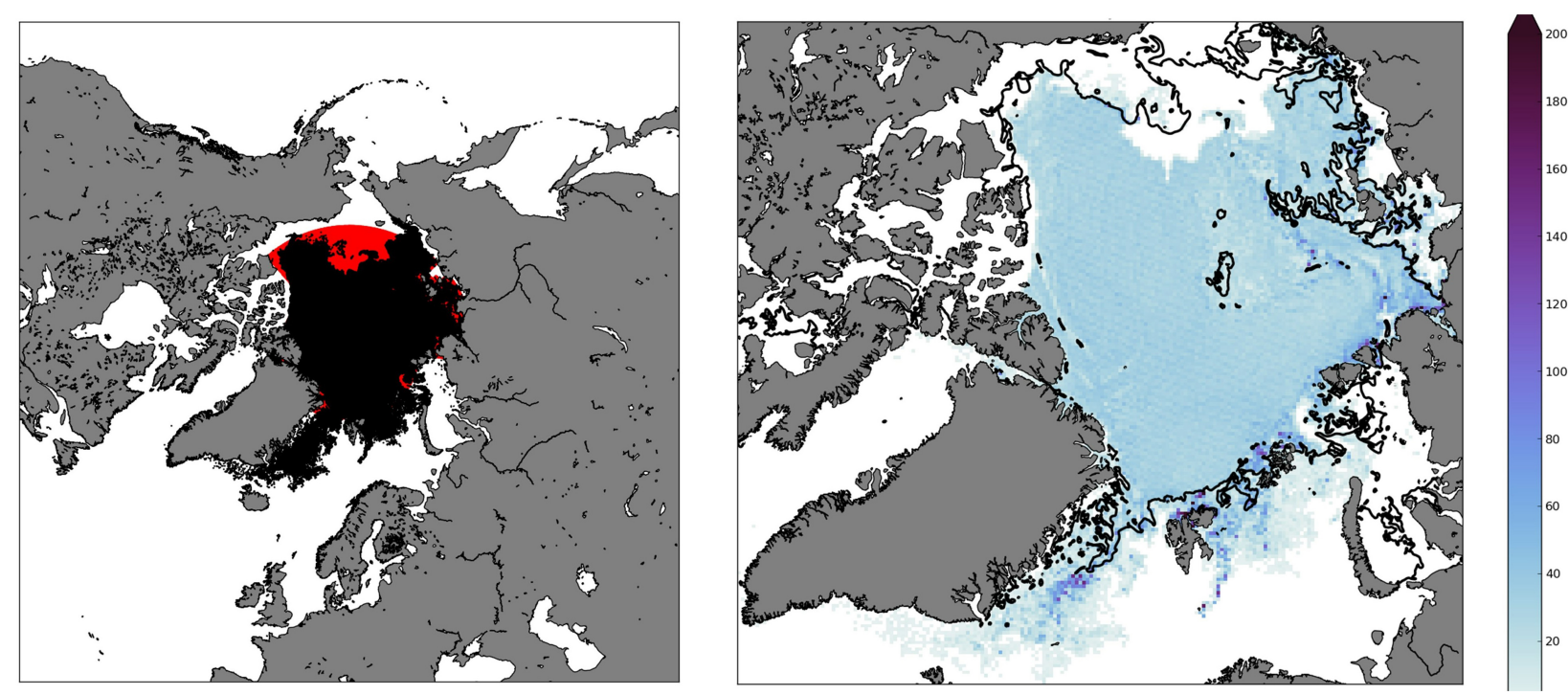

FIGURE 4 | (Left panel) Start position 1 April 2008 (red) and end position 31 July 2008 (black, superimposed) of tracked particles. (Right panel) particle density 31 July 2008 (color scale indicates particles per box, dividing the domain into a $200 \times 200$ grid), with the ice-edge (10\% ice cover) drawn as a black line.

April following this, particles that are located outside the sea ice are removed from the simulation. This leads to a year-toyear decline in particles for both migrating and non-migrating particles but at different rates.

\section{RESULTS}

\section{Particle Distribution Before Migration}

Since both the migrating and non-migrating model particles stayed at the ocean surface and followed the ice drift pattern during the first period (1 April 2008 - 31 July 2008), the trajectories of the two model scenarios were identical, and the end positions for the particles are shown in Figure 4. Clearly, the transport through the Fram Strait was significant, and particularly high concentrations of particles could be found in and south of the Fram Strait and in the marginal ice zone along the Barents and Kara Sea shelves. The ice drift in the Bering, Chukchi, and East Siberian Seas led to a northwards transport, resulting in large parts of the marginal ice zone in those shelf regions being devoid of $A$. glacialis during this period.

\section{Particle Distribution After First Vertical Migration}

From the 1 August 2008 and the onset of amphipod vertical migration in scenario 2 , the particle densities of the two scenarios differed, (Figure 5 shows the concentrations 1 April 2009 1 April 2010). It is clear that after the first period with deep vertical migration (Figure 5A) a visibly larger amount of the non-migrating particles was transported out through the Fram Strait with the Transpolar Drift, exiting the Eurasian Basin north of Svalbard. For the migrating particles that avoided the upper ocean transport toward the Fram Strait for large parts of the year, densities north of Svalbard and the Arctic Basin remained high, especially along the shelf break to the Kara Sea and the Siberian shelf, as well as the St. Anna Trough (Figure 5, right hand side). In contrast, the number of non-migrating particles in these areas are greatly reduced by 1 April 2010 (Figure 5, left hand side). Recounting the number of particles after 2 years of simulations (Figure 5C) for both scenarios revealed that about $88 \%$ of the migrating particles ended up in ice-covered waters, whereas only $62 \%$ of the non-migrating particles remained under ice.

\section{Particle Distribution After Reproductive and Mortality Events}

From 1 April 2010 the scenarios were run with the 1:2 reproduction rate and the mortality assessment (particles in open water by 1 April) as previously described. This led to an increase in total population numbers in both cases, but the vertically migrating population grew faster since a higher share of these particles were located within the ice every 1 April. The particle densities for both cases for each 1 April in the years 2010 - 2013 (Figure 6) showed clear differences between these two cases. The migrating particles were more evenly spread within the Arctic Ocean, except for low concentrations over the Siberian shelf. The non-migrating particles on the other hand largely exited the Eurasian Basin and were mostly located in high concentrations within the Beaufort Gyre domain in the Amerasian Basin. Also, the total amount of particles differed between the two populations, with the migrating particle number increasing at a higher rate. By 1 April 2013 the migrating population was nearly twofold larger, consisted of more than 1.4 million particles whereas the non-migrating population had reached about 750,000 particles. For the non-migrating particles, the seasonal reproduction was not enough to compensate for the 

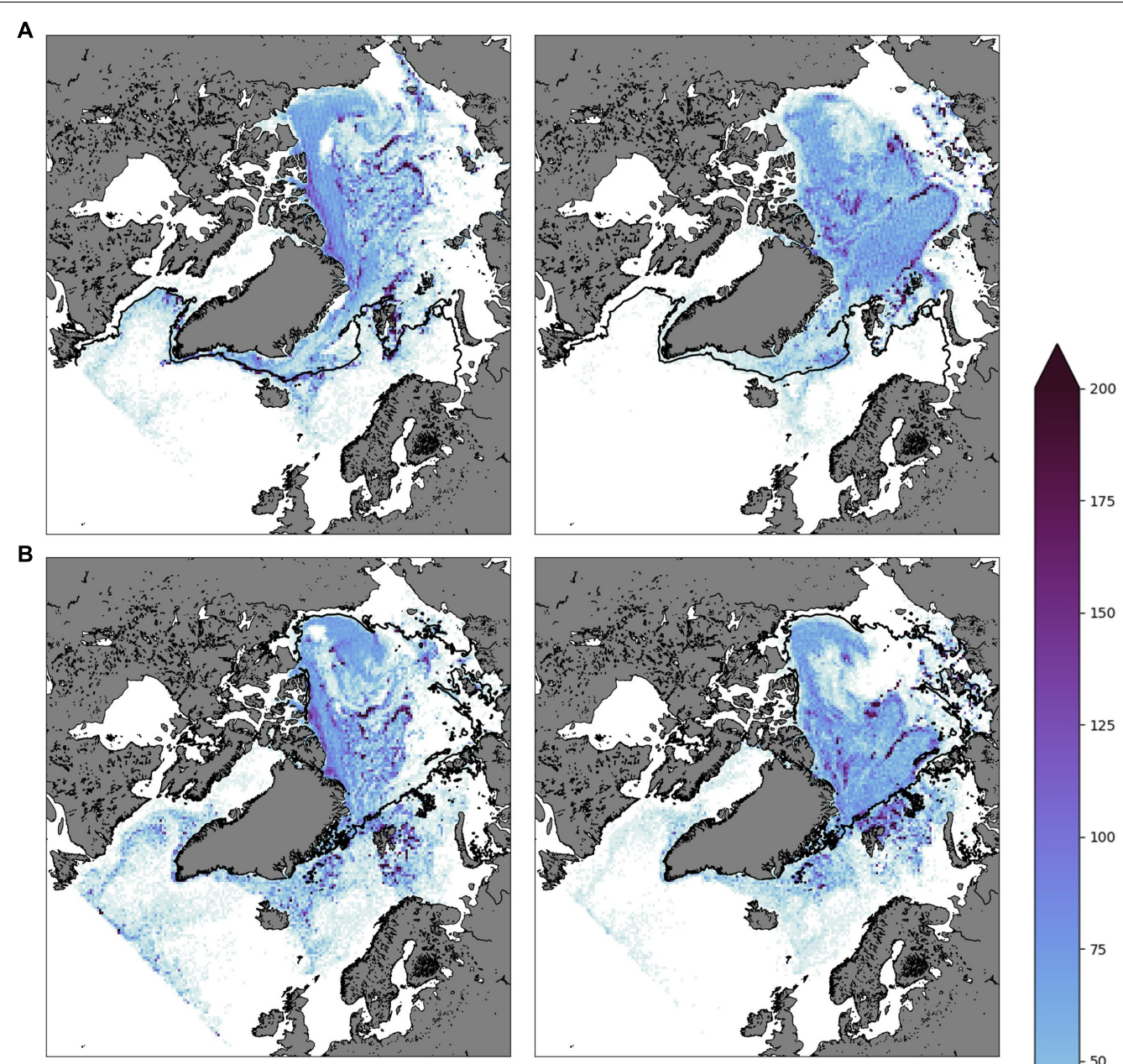

C
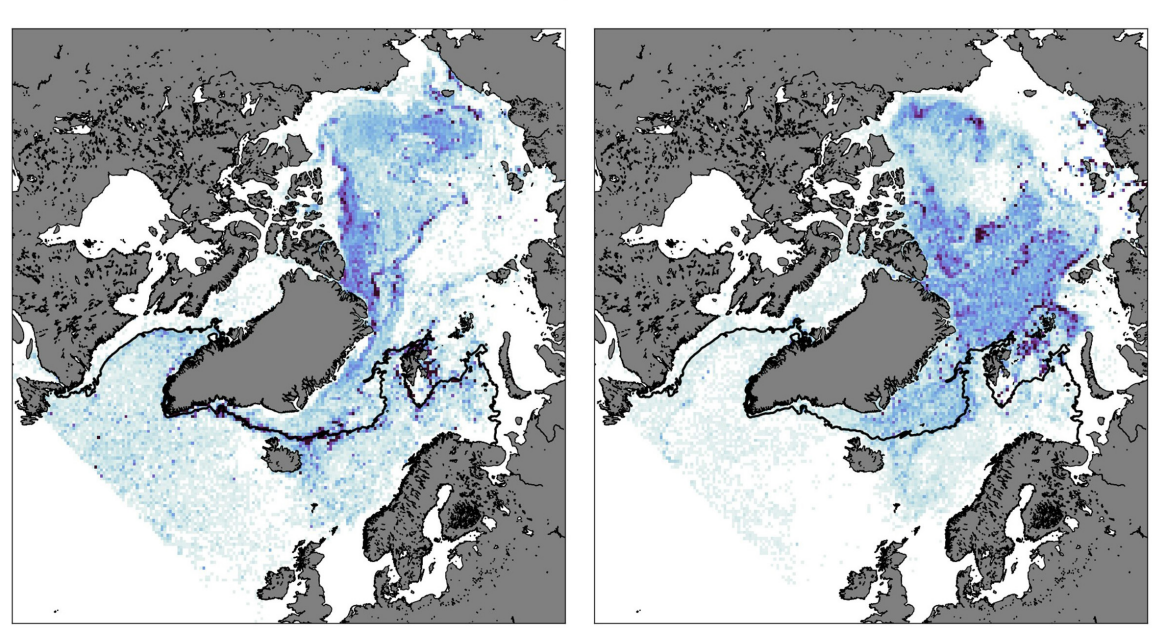

FIGURE 5 | Density plots of modeled particles for panel (A) 1 April 2009, (B) 1 August 2009, and (C) 1 April 2010. The left column represents the non-migrating scenario, while the right column represents the migrating scenario. Black line delineates $10 \%$ ice cover margin. The color scale indicates particles per box, dividing the domain into a $200 \times 200$ grid.

rapid transport away from the Eurasian Basin, leading to this area being largely devoid of particles by 1 April 2013. Particles that performed a vertical migration avoided the rapid transport of ice with the Transpolar Drift toward the Fram Strait for the winter period and could recolonize new ice the next spring when migrating back toward the surface. 


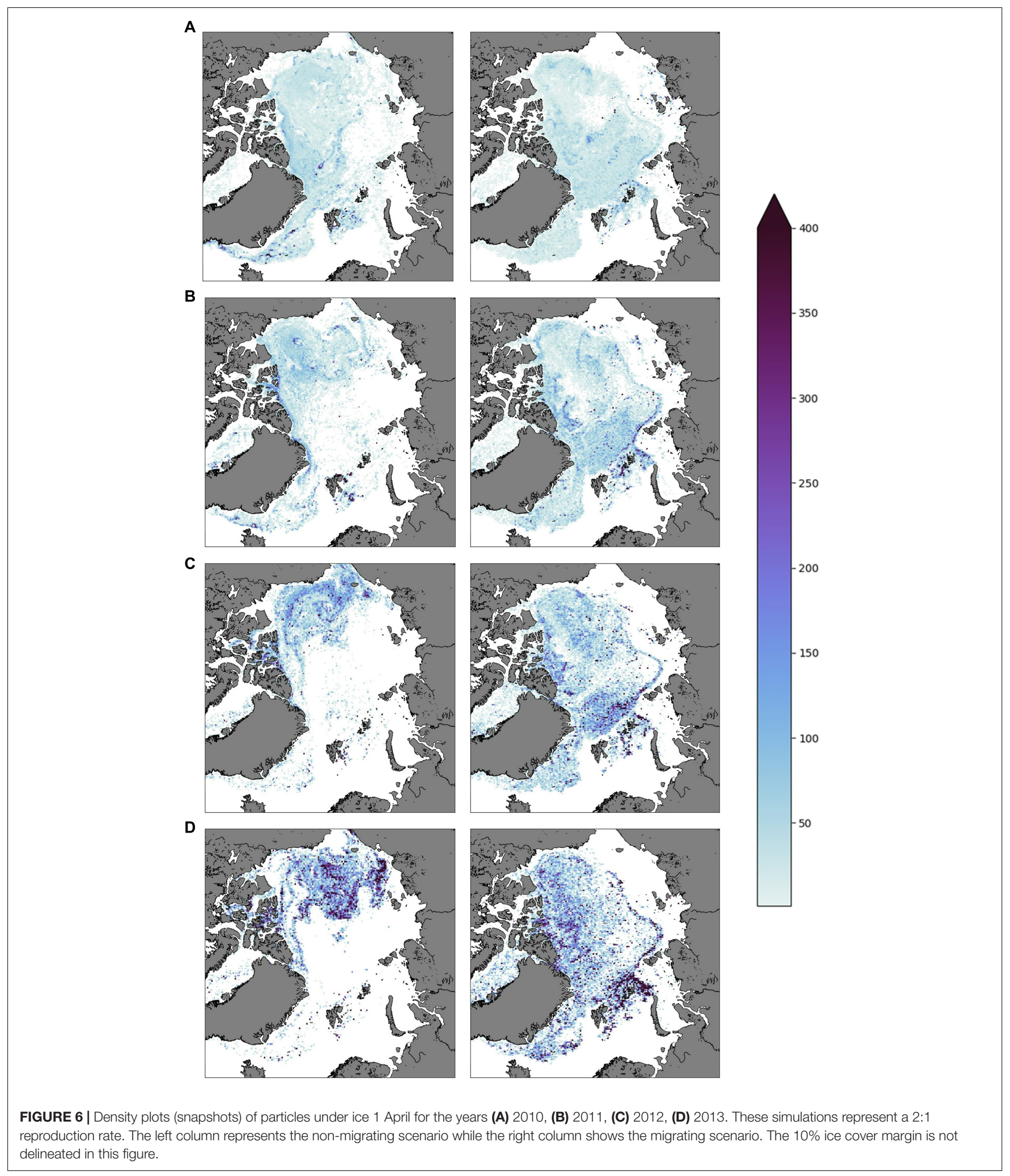

\section{Mortality Effect}

To get a longer-term perspective of mortality effects, both scenarios were rerun for a longer period (from 2010 to 2017), but assuming a lower reproductive rate where each particle in the ice was reseeded 1:1 every 1 April. This scenario in both cases (migrating and non-migrating) led to decreasing particle 

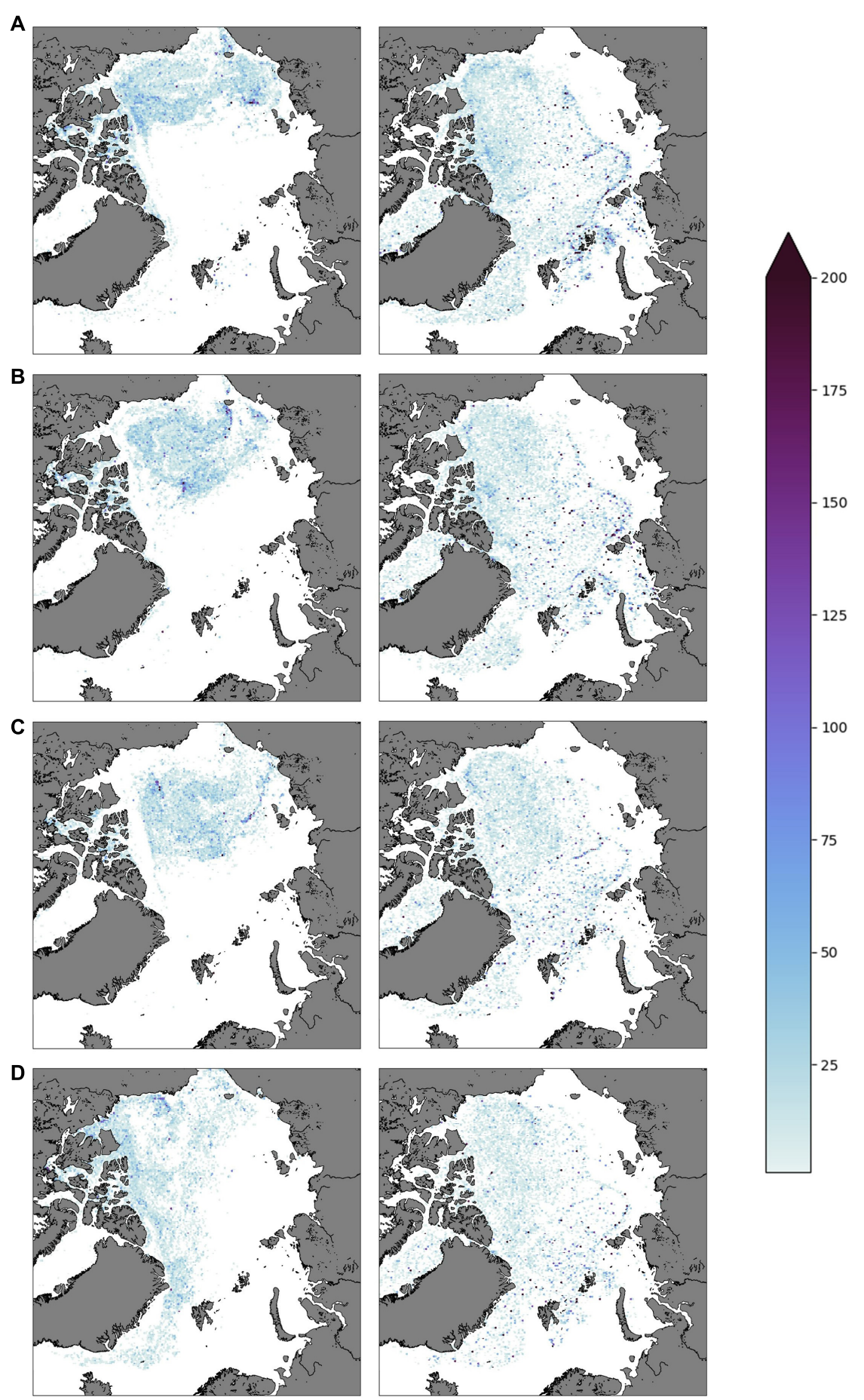

FIGURE 7 | Density plots (snapshots) of particles under ice 1 April for the years (A) 2014, (B) 2015, (C) 2016, (D) 2017. These simulations represent a 1:1 reproduction rate. The left column represents the non-migrating scenario while the right column shows the migrating scenario. Note that the color scale differs from Figure 6. The $10 \%$ ice cover margin is not delineated in this figure.

numbers. For these simulations, the distribution pattern was similar to what is shown in Figure 6 for the years 2010 - 2013, but with lower concentrations. The subsequent development for the years 2014 - 2017 is shown in Figure 7. For the non-migrating particles, the total population size initially dropped rapidly as most A. glacialis in the Eurasian Basin exited through the Fram Strait within the first few years. From 2013, the population size decreased at a much lower rate, as most remaining particles 
were located in the Amerasian Basin and tended to circulate the basin with the Beaufort Gyre rather than following the Transpolar Drift toward and exiting through the Fram Strait. The number of migrating particles decreased at a steadier yet slower pace, as the transport out through the Fram Strait was slowed due to the seasonal migration. From 2016 to 2017 the spreading pattern of the non-migrating particles shifted quite rapidly in that also particles in the Beaufort Gyre/Amerasian Basin moved toward the Fram Strait, indicating a change in the drift during this period.

\section{DISCUSSION}

In this paper we studied the possible effects of seasonal migration of the amphipod A. glacialis on their population size and distribution within the Arctic Ocean using a particle tracking model. In our simulations we separately ran the model with two scenarios: (a) A. glacialis that stay close to the surface, following the ice drift or surface current year-round and (b) A. glacialis that behave in the same manner 1 April to 31 July but perform a deep vertical migration staying at $250 \mathrm{~m}$ for the rest of the year. After the first summer (31 July 2008) the particles were evenly distributed in the Arctic Ocean, the GIN Seas and the Barents Sea. However, after the initial 2 years, the number of nonmigrating particles were reduced to nearly $60 \%$, while the number of migrating particles remained high, nearly $90 \%$ of the original. Another interesting result was that, as years progressed to 2013, the non-migrating particles were mostly retained in the icecovered Beaufort Gyre. Very few of the non-migrating particles were found in the central Arctic Ocean Basin, along the shelf break along Siberia, the shelf areas as well as the northern Barents Sea, in Svalbard waters, the Fram Strait and the Greenland Sea. The non-migrating particles were largely transported away from these areas and lost as the ice is melting. This is not surprising since the upper ocean currents in this region can lead to transport from the Siberian shelf to the Fram Strait within approximately 1 year (Timmermans and Marshall, 2020). On the other hand, the migrating particles were well distributed throughout the Arctic Ocean, along the shelf breaks, the Fram Strait and the northern Barents Sea.

The Transpolar Drift, along with the seasonal melting of sea ice in the Fram Strait, Greenland and Barents Seas, represents a large one-way transport of the core population of ice amphipods out of the Arctic Ocean. Accordingly, the ice amphipods (including $A$. glacialis) released as the ice melts over deep oceans, have been assumed to be permanently lost from their populations being subjected to predation in the pelagic system and/or become part of the vertical carbon flux (Lønne and Gabrielsen, 1992; Werner et al., 1999; Hop and Pavlova, 2008). Our findings, however, support the hypothesis of Berge et al. (2012) that $A$. glacialis instead reaches a more stable population size through performing a seasonal vertical migration. After they are transported by the ice drift into the GIN Seas, they migrate to depths in autumn and into the inflowing Atlantic Currents, being able to be transported back to the core population within the then ice-covered parts of the Arctic Basin. Further, our results suggest that without a seasonal vertical migration A. glacialis would be absent from most of the Arctic Ocean and a core population would only be maintained in the Beaufort Gyre. We argue that the seasonal vertical migration is a generally useful trait in lipid-rich, high-latitude herbivores as has been shown for the high-latitude Calanus copepods (Falk-Petersen et al., 2007, 2009).

\section{Is a Deep Migration Feasible?}

Our model output supports the concept that vertical migration behavior of $A$. glacialis as suggested based on observations of A. glacialis in deeper water layers in the Arctic Ocean (Berge et al., 2012; Kunisch et al., 2020) acts as a strategy that enhances survival and maintains a stable population in the ice-covered Arctic. Furthermore, since the suggested migrations are assumed to occur in the autumn after the peak of primary production it is a strategy that would not require additional energy reserves for the period the species would spend at depth. Apherusa glacialis is a mainly herbivorous species feeding on ice algae as well as phytoplankton when those sources are available (Scott et al., 1999; Kohlbach et al., 2016). During that time, it builds up lipid resources resulting in high lipid content from 45 to $60 \%$ lipids of dry mass (Berge et al., 2012; Kohlbach et al., 2016). These are lipid levels on par with those found for other key Arctic herbivorous species such as the copepods Calanus finmarchicus, C. glacialis, and C. hyperboreus. These three Calanus species are known for their unique life history strategies, feeding on high latitude blooms until they have filled their lipid depots, then migrating to depth for overwintering (Conover and Huntley, 1991; Falk-Petersen et al., 2000, 2009; Lee et al., 2006). While the benefits of diel vertical migrations are linked to predator avoidance, those of seasonal vertical migration have rather been linked to enduring the food-poor season (for herbivores) with lowered metabolic rates outside the often colder surface while subsiding on stored energy (Hagen, 1999). Apherusa glacialis also has the energy reserves needed to survive a long winter without feeding (Werner and Auel, 2005). Arctic blooms, consisting of ice algae and pelagic phytoplankton, are spatially variable and can occur at any time between March and September, dependent on light, nutrients, ice conditions, leads and opening in the sea ice, and upwelling of nutrients through the halocline in the Arctic Ocean and along the shelf break (Zenkevich, 1963; Daase et al., 2013; Ardyna et al., 2014; Falk-Petersen et al., 2015; Darnis et al., 2019; Randelhoff et al., 2020). The three Calanus species have life history strategies which are geared to different bloom situations. While C. finmarchicus mainly feeds on the traditional spring - summer bloom, the two other species being larger in size with large lipid stores, can utilize the bloom at any time during the primary production period between the spring and autumn equinoxes (Falk-Petersen et al., 2000). As soon as the Calanus species have filled up their lipid reserves they will migrate down to depth being transported by the interconnected current system inside and outside of the Arctic Ocean (Falk-Petersen et al., 2007). The seasonal migration to deep waters can take place as early as May - June and as late as September (Falk-Petersen et al., 2009). The present study, together with records of pelagic occurrences (Kunisch et al., 2020) and high lipid content (Berge et al., 2012; Kohlbach et al., 2016) suggest that similar strategies are 
conceivable for a sympagic species such as A. glacialis. Whether or not A. glacialis is actively feeding during the phase at depth is unclear, though recent trophic marker studies suggest they may continue feeding (Kunisch et al., unpubl. data).

Another important part of the life history of A. glacialis that needs to be considered in evaluating the feasibility and ecological role of deep vertical migration is its life cycle. Apherusa glacialis has a lifespan of 2 years (Melnikov and Kulikov, 1980; Poltermann, 1998). Though it has initially been assumed to have a high fecundity compared to most gammarid amphipods with 370-727 eggs per female year ${ }^{-1}$ (Poltermann, 2000), our recent observations show the number of eggs to be much lower (pers. obs. by author group, Figure 2). The here evaluated deep vertical migration is consistent with in situ observations that gravid A. glacialis females are more or less absent from spring to fall when these amphipods can be abundant under sea ice. Gravid females have, however, lately been regularly observed in deeper layers of the Arctic Ocean north of Svalbard in polar night months (Berge et al., 2012; Kunisch et al., 2020). In terms of required energy reserves and development, a deep migration in the polar night to layers consisting of water masses with temperatures several degrees higher than those found close to the sea ice might be advantageous for the developing juveniles carried in the brood pouch of the female. In spring, high numbers of freshly hatched juvenile stages (1-2 mm body length) directly under sea ice indicate upward migration of females with fully developed juveniles (or even of juveniles themselves) by that time. This timing is thought to take advantage of the ice algal spring bloom in sea ice (Kunisch et al., 2020) that precedes the pelagic bloom by weeks to months (Leu et al., 2015; Wassmann et al., 2020).

\section{Model Set-up, Performance, and Caveats}

With the model approach used in this study we simulated the trajectories of A. glacialis following both the sea-ice drift and ocean currents for several years. The current model setup is clearly a simplistic first step to link the life strategy of A. glacialis to the Arctic hydrographic conditions, and future modifications to the model could reveal more details. Future runs could be modified to use observation-based abundance estimates of A. glacialis including their spatial variation. This species is the most abundant of sympagic amphipods with densities that vary from 0 to $>150$ ind. $\mathrm{m}^{-2}$ with large spatial variation at multiple scales (Kunisch et al., 2020). Highest values reported are from around Svalbard and the Beaufort shelf, and lowest from the Beaufort Gyre (synthesized in Bluhm et al., 2017). Apherusa glacialis have not been reported from the Bering and southern Chukchi Seas (ibid.). In addition, experimental work focused on reproductive success could constrain a reproductive ratio closer to reality. Here our model estimates that a reproductive rate between 1:1 (loss) and 1:2 (increasing populations) would result in near constant abundances.

We chose a migration depth of $250 \mathrm{~m}$, based on a combination of highest current velocities thereabouts in the core Atlantic layer in the Atlantic inflow region (Bluhm et al., 2020; Polyakov et al., 2020) and known vertical migration behavior of Calanoid copepods (Søreide et al., 2010; Daase et al., 2013). Modeled outputs (especially years 2012 and 2013, Figures 6C,D) showed the effect of this choice in enhanced $A$. glacialis particle concentrations at the shelf break in the Kara and Siberian Seas where the Arctic Circumpolar Boundary Current (ACBC) is the likely vector and reaches velocities on the order of $20 \mathrm{~cm} \mathrm{~s}^{-1}$ (Bluhm et al., 2020). We did not adjust particle depth although we are aware that the ACBC eventually becomes deeper during its transit into and throughout the Amerasian Basin (Bluhm et al., 2020). Adjusting the migration depth according to the ACBC could result in the particles following the current trajectory more closely. So far, however, the observational evidence rather suggests that $A$. glacialis may occupy several depths (Kunisch et al., 2020). Considering this, the choice of a constant migrating depth probably underestimates the spread of the migrating particles. The more important finding, however, is that the higher numbers of migrating than non-migrating particles retained inside the Arctic Ocean largely stems from avoiding the major export with the ice in the winter months through the Fram Strait, which indicates that a pelagic state at any depth is advantageous for the retention in the Arctic. In the model simulations the migrating A. glacialis all undertake a deep migration at fixed dates and are assumed to passively stay at depth for the entire period from 1 August to 31 March the following year. This is clearly a simplification that possibly leads to an overestimated difference in the spreading pattern between the migrating and non-migrating particles. Algal productivity in the Arctic Ocean can occur also past August 1, as recently shown through remotely sensed algal autumn blooms (Ardyna and Arrigo, 2020). A more likely vertical movement pattern is that the deep migration is restricted to a shorter period. Furthermore, it seems reasonable to assume that the timing of the migration is more flexible and could be triggered at an individual and regional level, by e.g., lipid reserves being filled or by reduced sea ice extent or food concentrations. This is also more in line with the fact that A. glacialis can be found in the entire water column throughout the year (Kunisch et al., 2020). Adding individual behavior such as feeding to the model would require information about the quantity of food sources. A possible approach to this could be to run a coupled hydrodynamic, sea ice and biogeochemical model system that simulates e.g., ice algae blooms. However, running such a coupled system would greatly increase the computational cost. An advantage of the simpler approach in this study is the computational efficiency and hence the possibility to run simulations with a large number of particles. We consider therefore our approach as a first step to investigate the possible effect of vertical deep migration of $A$. glacialis. Although the simplified migration pattern introduces uncertainty, the clear results from the simulations show that a vertical deep migration will have a large impact on the spreading of this species.

The model simulations showed a change in the drift pattern during 2016-2017, as non-migrating particles that were in the Beaufort Gyre and Amerasian Basin drifted quite rapidly toward the Fram Strait. This feature is possibly related to the unusual sea ice cover pattern in 2016, which exhibited a record-low sea ice extent at the start of the year followed by a higher-than-expected sea ice extent in July-September and a record late freeze-up in the central Arctic (Petty et al., 2018). 


\section{CONCLUSION}

Seasonal vertical migration considerably enhanced both the survival of $A$. glacialis and its retention within the Arctic Ocean region in our model. With a simplified parametrization of reproduction/mortality, the population increased from a factor slightly above 2 to a factor of 4 over the course of 5 years when vertical migration was included. We suggest that this behavior will increase survival in a warmer Arctic with little sea ice. If this pattern holds true even for a fully ice-free Arctic, however, remains questionable, and additional targeted sampling will be beneficial. Targeted sampling would help our understanding if A. glacialis conducts vertical migrations en masse, similar to Calanus spp. One way to further test this hypothesis is by conducting a population genetics study in which we would hypothesize less genetic structure if A. glacialis was indeed conducting seasonal vertical migration, while we would expect more genetic differences if the species was entirely sympagic and more constrained to either the Transpolar Drift or the Beaufort Gyre systems.

\section{DATA AVAILABILITY STATEMENT}

The raw data supporting the conclusions of this article will be made available by the authors, without undue reservation.

\section{REFERENCES}

Aksenov, Y., Ivanov, V. V., Nurser, A. J. G., Bacon, S., Polyakov, I. V., Coward, A. C., et al. (2011). The Arctic circumpolar boundary current. J. Geophys. Res. 116:09017. doi: 10.1029/2010JC006637

Andersson, M., Orvik, K. A., LaCasce, J. H., Koszalka, I., and Mauritzen, C. (2011). Variability of the Norwegian Atlantic current and associated eddy field from surface drifters. J. Geophys. Res. 116:C08032. doi: 10.1029/2011JC007078

Ardyna, M., and Arrigo, K. R. (2020). Phytoplankton dynamics in a changing Arctic Ocean. Nat. Clim. Chang. 10, 892-903. doi: 10.1038/s41558-020-0905-y

Ardyna, M., Babin, M., Gosselin, M., Devred, E., Rainville, L., and Tremblay, J. -É (2014). Recent Arctic Ocean sea ice loss triggers novel fall phytoplankton blooms. Geophys. Res. Lett. 41, 6207-6212. doi: 10.1002/2014GL061047

Arndt, C. E., and Swadling, K. M. (2006). Crustacea in Arctic and Antarctic sea ice: distribution, diet and life history strategies. Adv. Mar. Biol. 51, 197-315. doi: 10.1016/S0065-2881(06)51004-1

Barnard, J. L. (1959). Epipelagic and under-ice Amphipoda of the Central Arctic Basin. Scientific studies at Fletcher's Ice Island, T-3. Geophys. Res. Pap. 63, 115-153.

Berge, J., Varpe, Ø, Moline, M. A., Wold, A., Renaud, P. E., Daase, M., et al. (2012). Retention of ice-associated amphipods: possible consequences for an ice-free Arctic Ocean. Biol. Lett. 8, 1012-1015. doi: 10.1098/rsbl.2012.0517

Beuchel, F., and Lønne, O. J. (2002). Population dynamics of the sympagic amphipods Gammarus wilkitzkii and Apherusa glacialis in sea ice north of Svalbard. Polar Biol. 25, 241-250. doi: 10.1007/s00300-0010329-8

Bluhm, B. A., Gebruk, A. V., Gradinger, R., Hopcroft, R. R., Huettmann, F., Kosobokova, K. N., et al. (2011). An update of species richness and examples of biodiversity change. Oceanography 24, 232-248. doi: 10.5670/oceanog.2011.75

Bluhm, B. A., Hop, H., Melnikov, I. A., Poulin, M., Vihtakari, M., Collins, R. E., et al. (2017). "Sea ice biota " in CAFF. State of the Arctic Marine Biodiversity Report. Conservation of Arctic Flora and Fauna, eds T. Barry, C. Price, M. Olsen, T. Christensen, and M. Frederiksen (Akureyri: International Secretariat).

Bluhm, B. A., Janout, M. A., Danielson, S. L., Ellingsen, I., Gavrilo, M., Grebmeier, J. M., et al. (2020). The pan-Arctic continental slope: sharp gradients of physical

\section{AUTHOR CONTRIBUTIONS}

MD performed the particle tracking modeling, the model postprocessing and visualization of results. SF-P and MD wrote the first draft of the manuscript. All authors contributed to the manuscript revision, read and approved the submitted version and conception and design of the study and analysis of model results, and wrote sections of the manuscript.

\section{FUNDING}

This work was supported by two grants from the Norwegian Research Council: Arctic ABC (project no 244319) and Deep Impact (project no 300333) in addition to the Centre of Excellence AMOS (project no 223254). This is a contribution to the Arctos research network (arctos.uit.no), Arctic Science Partnership (www.asp-net.org) and the Arctic-SIZE programme funded by UiT.

\section{ACKNOWLEDGMENTS}

We appreciate fruitful discussions with Arctic $A B C$ project associates, in particular N. Banas, F. Cottier, L. Hobbs, M. Daase, K. Last, P. Renaud, and Ø. Varpe.

processes affect pelagic and benthic ecosystems. Front. Mar. Sci. 7:886. doi: 10.3389/fmars.2020.544386

Budgell, W. P. (2005). Numerical simulation of ice-ocean variability in the Barents sea region towards dynamical downscaling. Ocean Dyn. 55, 370-387. doi: 10. 1007/s10236-005-0008-3

Conover, R. J., and Huntley, M. (1991). Copepods in ice-covered seas distribution, adaptations to seasonally limited food, metabolism, growth patterns and life cycle strategies in polar seas. J. Mar. Syst. 2, 1-41. doi: 10.1016/ 0924-7963(91)90011-I

Daase, M., Berge, J., Søreide, J. E., and Falk-Petersen, S. (2021). "Ecology of Arctic pelagic communities," in Arctic Ecology, ed. D. N. Thomas (Hoboken, NJ: Wiley Blackwell), 219-259. doi: 10.1002/9781118846582.ch9

Daase, M., Falk-Petersen, S., Varpe, Ø, Darnis, G., Søreide, J. G., Wold, A., et al. (2013). Timing of reproductive events in the marine copepod Calanus glacialis: a pan-Arctic perspective. Can. J. Fish. Aquat. 70, 871-884. doi: 10.1139/cjfas2012-0401

Darnis, G., Wold, A., Falk-Petersen, S., Graeve, M., and Fortier, L. (2019). Could offspring predation offset the successful reproduction of the arctic copepod Calanus hyperboreus under reduced sea-ice cover conditions? Progr. Oceanogr. 170, 107-118. doi: 10.1016/j.pocean.2018.11.004

Dee, D. P., Uppala, S. M., Simmons, A. J., Berrisford, P., Poli, P., Kobayashi, S., et al. (2011). The ERA-interim reanalysis: configuration and performance of the data assimilation system. Q. J. R. Meteorol. Soc. 137, 553-597. doi: 10.1002/qj.828

Döös, K., Jönsson, B., and Kjellson, J. (2017). Evaluation of oceanic and atmospheric trajectory schemes in the TRACMASS trajectory model v6.0. Geosci. Model. Dev. 10, 1733-1749. doi: 10.5194/gmd-10-1733-2017

Döös, K., Kjellsson, J., and Jönsson, B. (2013). "TRACMASS-a Lagrangian trajectory model," in Preventive Methods for Coastal Protection, eds T. Soomere and E. Quak (Heidelberg: Springer), doi: 10.1007/978-3-319-00440-2_7

Egbert, G. D., and Erofeeva, S. Y. (2002). Efficient inverse modeling of barotropic ocean tides. J. Atmos. Ocean. Technol. 19, 183-204. doi: 10.1175/152004262002019<0183:EIMOBO<2.0.CO;2

Ehrlich, J., Schaafsma, F. L., Bluhm, B. A., Peeken, I., Castellani, G., Brandt, A., et al. (2020). Sympagic Fauna in and under Arctic pack ice in the Annual Sea-ice system of the new Arctic. Front. Mar. Sci. 7:452. doi: 10.3389/fmars.2020.00452 
Falk-Petersen, S., Hop, H., Budgell, W. P., Hegseth, E. N., Korsnes, R., Løyning, T. B., et al. (2000). Physical and ecological processes in the marginal ice zone of the northern Barents Sea during the summer melt period. J. Mar. Syst. 27, 131-159. doi: 10.1016/S0924-7963(00)00064-6

Falk-Petersen, S., Mayzaud, P., Kattner, G., and Sargent, J. R. (2009). Lipids and life strategy of Arctic Calanus. Mar. Biol. Res. 5, 18-39. doi: 10.1080/ 17451000802512267

Falk-Petersen, S., Pavlov, V., Berge, J., Cottier, F., Kovacs, K. M., and Lydersen, C. (2015). At the rainbow's end: high productivity fueled by winter upwelling along an Arctic shelf. Polar Biol. 38, 5-11. doi: 10.1007/s00300-014-1482-1

Falk-Petersen, S., Pavlov, V., Timofeev, S., and Sargent, J. R. (2007). "Climate variability and possible effects on arctic food chains: the role of Calanus," in Arctic Alpine Ecosystems and People in a Changing Environment, eds J. B. Ørbæk, R. Kallenborn, I. Tombre, E. N. Hegseth, S. Falk-Petersen, and A. H. Hoel (Berlin: Springer).

Gradinger, R., and Bluhm, B. A. (2004). In-situ observations on the distribution and behavior of amphipods and Arctic cod (Boreogadus saida) under the sea ice of the high Arctic Canada Basin. Polar Biol. 27, 595-603. doi: 10.1007/s00300004-0630-4

Gradinger, R., and Bluhm, B. A. (2020). First analysis of an Arctic sea ice meiofauna food web based on abundance, biomass and stable isotope ratios. Mar. Ecol. Prog. Ser. 634, 29-43. doi: 10.3354/meps13170

Gulliksen, B., and Lønne, O. J. (1991). Sea ice macrofauna in the Antarctic and the Arctic. J. Mar. Syst. 2, 53-61. doi: 10.1016/0924-7963(91)90013-K

Hagen, W. (1999). Reproductive strategies and energetic adaptations of polar zooplankton. Invertebr. Reprod. Dev. 36, 25-34. doi: 10.1080/07924259.1999. 9652674

Hansen, B., and Østerhus, S. (2000). North Atlantic-Nordic Seas exchanges. Progr. Oceanogr. 45, 109-208. doi: 10.1016/S0079-6611(99)00052-X

Hattermann, T., Isachsen, P. E., von Appen, W. J., Albretsen, J., and Sundfjord, A. (2016). Eddy-driven recirculation of Atlantic water in fram strait. Geophys. Res. Lett. 43, 3406-3414. doi: 10.1002/2016GL068323

Helland-Hansen, B., and Nansen, F. (1909). The Norwegian Sea, It's Physical Oceanography Based on the Norwegian Researches 1900-1904. Report on Norwegian Fishery and Marine-Investigations 11, Vol. 2. Kristiania: Det Mallingske Bogtrykkeri.

Hop, H., Falk-Petersen, S., Svendsen, H., Kwasniewski, S., Pavlova, V., Pavlova, O., et al. (2006). Physical and biological characteristics of the pelagic system across fram strait to Kongsfjorden. Prog. Oceanogr. 71, 182-231. doi: 10.1016/j.pocean. 2006.09.007

Hop, H., and Pavlova, O. (2008). Distribution and biomass transport of ice amphipods in drifting sea ice around Svalbard. Deep Sea Res. II Top. Stud. Oceanogr. 55, 2292-2307. doi: 10.1016/j.dsr2.2008.05.023

Kohlbach, D., Graeve, M. A., Lange, B., David, C., Peeken, I., and Flores, H. (2016). The importance of ice algae-produced carbon in the central Arctic Ocean ecosystem: food web relationships revealed by lipid and stable isotope analyses. Limnol. Oceanogr. 61, 2027-2044. doi: 10.1002/lno.10351

Kovacs, K. M., Lydersen, C., Overland, J. E., and Moore, S. E. (2011). Impacts of changing sea-ice conditions on Arctic marine mammals. Mar. Biodivers. 41, 181-194. doi: 10.1007/s12526-010-0061-0

Kunisch, E. H., Bluhm, B. A., Daase, M., Gradinger, R., Hop, H., Melnikov, I. A., et al. (2020). Pelagic occurrences of the ice amphipod Apherusa glacialis throughout the Arctic. J. Plankton Res. 42, 73-86. doi: 10.1093/plankt/fbz072

Laidre, K. L., Stirling, I., Lowry, L. F., Wiig, $\varnothing$, Heide-Jørgensen, M. P., and Ferguson, S. H. (2008). Quantifying the sensitivity of Arctic marine mammals to climate-induced habitat change. Ecol. Appl. 18, 97-125. doi: 10.1890/06-0546.1

Lee, R. F., Hagen, W., and Kattner, G. (2006). Lipid storage in marine zooplankton. Mar.Ecol. Progr. Ser. 307, 273-306. doi: 10.3354/meps307273

Leu, E., Mundy, C. J., Assmy, P., Campbell, K., Gabrielsen, T. M., Gosselin, M., et al. (2015). Arctic spring awakening - Steering principles behind the phenology of vernal ice algal blooms. Progr. Oceanogr. 139, 151-170. doi: 10.1016/j.pocean. 2015.07.012

Lind, S., and Ingvaldsen, R. B. (2012). Variability and impacts of Atlantic water entering the Barents Sea from the north. Deep Sea Res. Part I 62, 70-88. doi: 10.1016/j.dsr.2011.12.007

Lind, S., Ingvaldsen, R. B., and Furevik, T. (2016). Arctic layer salinity controls heat loss from deep Atlantic layer in seasonally ice-covered areas of the Barents Sea. Geophys. Res. Lett. 43, 5233-5242. doi: 10.1002/2016GL068421
Loeng, H. (1991). Features of the physical oceanographic conditions in the Barents Sea. Polar Res. 10, 5-18. doi: 10.3402/polar.v10i1.6723

Lønne, O. J., and Gabrielsen, G. W. (1992). Summer diet of seabirds feeding in sea-ice-covered waters near Svalbard. Polar Biol. 12, 685-692. doi: 10.1007/ BF00238868

Lønne, O. J., and Gulliksen, B. (1991b). Sympagic macro-fauna from multiyear sea-ice near Svalbard. Polar Biol. 11, 471-477. doi: 10.1007/BF00233082

Lønne, O. J., and Gulliksen, B. (1991a). Source, density and composition of sympagic fauna in the Barents Sea. Polar Res. 10, 289-294. doi: 10.3402/polar. v10i1.6747

Macnaughton, M. O., Thormar, J., and Berge, J. (2007). Sympagic amphipods in the Arctic pack ice: redescriptions of Eusirus holmii Hansen, 1887 and Pleusymtes karstensi (Barnard, 1959). Polar Biol. 30, 1013-1025. doi: 10.1007/s00300-0070260-8

Melnikov, A. (1997). Arctic Sea Ice Ecosystem. Boca Raton, FL: CRC Press.

Melnikov, I. A., and Kulikov, A. S. (1980). "The cryopelagic fauna of the central Arctic basin," in Biology of the Central Arctic Basin, eds M. E. Vinogradov and I. A. Mel'nikov (Moscow: Nauka), 97-111.

Menze, S., Ingvaldsen, R. B., Haugan, P., Beszczynska-Moeller, A., Fer, I., Sundfjord, A., et al. (2019). Atlantic water pathways along the north-western Svalbard shelf mapped using vessel-mounted current profilers. J. Geophys. Res. Oceans 124, 1699-1716. doi: 10.1029/2018JC014299

Nansen, F. (1902). Oceanography of the North Polar Basin. The Norwegian North Polar Expedition 1893-1896. Scientific Results, Vol. 9. New York, NY: Greenwood Press, 427.

Ogi, M., Yamazaki, K., and Wallace, J. M. (2010). Influence of winter and summer surface wind anomalies on summer Arctic sea ice extent. Geophys. Res. Lett. 37:L07701. doi: 10.1029/2009GL042356

Petty, A. A., Stroeve, J. C., Holland, P. R., Boisvert, L. N., Bliss, A. C., Kimura, N., et al. (2018). The Arctic sea ice cover of 2016: a year of record-low highs and higher-than-expected lows. Cryosphere 12, 433-452. doi: 10.5194/tc-12-4332018

Poltermann, M. (1998). Abundance, biomass and small-scale distribution of cryopelagic amphipods in the Franz Josef Land area (Arctic). Polar Biol. 20, 134-138. doi: 10.1007/s003000050287

Poltermann, M. (2000). Growth, production and productivity of the Arctic sympagic amphipod Gammarus wilkitzkii. Mar. Ecol. Prog. Ser. 193, 109-116. doi: $10.3354 /$ meps193109

Poltermann, M. (2001). Arctic sea ice as feeding ground for amphipods-food sources and strategies. Polar Biol. 24, 89-96. doi: 10.1007/s003000000177

Poltermann, M., Hop, H., and Falk-Petersen, S. (2000). Life under Arctic sea icereproduction strategies of two sympagic (ice-associated) amphipod species, Gammarus wilkitzkii and Apherusa glacialis. Mar. Biol. 136, 913-920. doi: 10. 1007/s002270000307

Polyakov, I. V., Alkire, M. B., Bluhm, B. A., Brown, K. A., Carmack, E. C., Chierici, M., et al. (2020). Borealization of the Arctic Ocean in response to anomalous advection from sub-Arctic seas. Front. Mar. Sci. 7:491. doi: 10.3389/fmars.2020. 00491

Poulin, M., Daugbjerg, N., Gradinger, R., Ilyash, L., Ratkova, T., and von Quillfeldt, C. (2011). The pan-Arctic biodiversity of marine pelagic and sea-ice unicellular eukaryotes: a first-attempt assessment. Mar. Biodivers. 41, 13-28. doi: 10.1007/ s12526-010-0058-8

Rachold, V., Eicken, H., Gordeev, V. V., Grigoriev, M. N., Hubberten, H. W., and Lisitzin, A. P. (2004). "Modern terrigenous organic carbon input to the Arctic ocean," in The Organic Carbon Cycle in the Arctic Ocean, eds R. Stein and R. W. MacDonald (Berlin: Springer), 33-55.

Randelhoff, A., Holding, J., Janout, M., Sejr, M. K., Babin, M., Tremblay, J. -É, et al. (2020). Pan-Arctic ocean primary production constrained by turbulent nitrate fluxes. Front. Mar. Sci. 7:150. doi: 10.3389/fmars.2020.00150

Rudels, B. (2015). Arctic Ocean circulation, processes and water masses: a description of observations and ideas with focus on the period prior to the International Polar Year 2007-2009. Progr. Oceanogr. 132, 22-67. doi: 10.1016/ j.pocean.2013.11.006

Rudels, B., Meyer, R., Fahrbach, E., Ivanov, V. V., Østerhus, S., Quadfasel, D., et al. (2000). Water mass distribution in fram strait and over the Yermak Plateau in summer 1997. Ann. Geophys. 18, 687-705. doi: 10.1007/s00585-000-0687-5

Rudels, B., Schauer, U., Björk, G., Korhonen, M., Pisarev, S., Rabe, B., et al. (2013). Observations of water masses and circulation with focus on the Eurasian basin 
of the Arctic Ocean from the 1990s to the late 2000s. Ocean Sci. J. 9, 147-169. doi: 10.5194/os-9-147-2013

Scott, C. L., Falk-Petersen, S., Sargent, J. R., Hop, H., Lønne, O. J., and Poltermann, M. (1999). Lipids and trophic interactions of ice fauna and pelagic zooplankton in the marginal ice zone of the Barents Sea. Polar Biol. 21, 65-70. doi: 10.1007/ s003000050335

Semper, S., Pickart, R. S., Våge, K., Torres, D. J., and McRaven, L. (2020). CTD Temperature and Salinity Profiles Along Five Transects in NE Iceland / IcelandFaroe Ridge. PANGAEA. doi: 10.1594/PANGAEA.919516

Shchepetkin, A. F., and McWilliams, J. C. (2005). The regional oceanic modeling system (ROMS): a split-explicit, free-surface, topography-following-coordinate oceanic model. Ocean Model. 9, 347-404. doi: 10.1016/j.ocemod.2004. 08.002

Søreide, J. E., Leu, E., Berge, J., Graeve, M., and Falk-Petersen, S. (2010). Timing of blooms, algal food quality and Calanus glacialis reproduction and growth in a changing Arctic. Glob. Chang. Biol. 16, 3154-3163. doi: 10.1111/j.1365-2486. 2010.02175.x

Spreen, G., de Steur, L., Divine, D., Gerland, S., Hansen, E., and Kwok, R. (2020). Arctic sea ice volume export through fram strait from 1992 to 2014. J. Geophys. Res. Oceans 125:e2019JC016039. doi: 10.1029/2019JC016039

Spreen, G., Kwok, R., and Menemenlis, D. (2011). Trends in Arctic sea ice drift and role of wind forcing: 1992-2009. Geophys. Res. Lett. 38:L19501. doi: 10.1029/ 2011GL048970

Storkey, D., Blockley, E. W., Furner, R., Guiavarc'h, C., Lea, D., Martin, M. J., et al. (2010). Forecasting the ocean state using NEMO: the new FOAM system. J. Oper. Oceanogr. 3, 3-15. doi: 10.1080/1755876X.2010.1102 0109

Stroeve, J. C., Kattsov, V., Barrett, A., Serreze, M., Pavlova, T., Holland, M., et al. (2012). Trends in Arctic sea ice extent from CMIP5, CMIP3 and observations. Geophys. Res. Lett. 39:L16502. doi: 10.1029/2012GL052676

Timmermans, M.-L., and Marshall, J. (2020). Understanding Arctic ocean circulation: a review of ocean dynamics in a changing climate. J. Geophys. Res. Oceans 125:e2018JC014378. doi: 10.1029/2018JC014378

Wassmann, P., Carmack, E. C., Bluhm, B. A., Duarte, C. M., Berge, J., Brown, K., et al. (2020). Towards a unifying pan-arctic perspective: a conceptual modelling toolkit. Progr. Oceanogr. 189:102455. doi: 10.1016/j.pocean.2020.10 2455

Wassmann, P., Reigstad, M., Haug, T., Rudels, B., Carroll, M. L., Hop, H., et al. (2006). Food webs and carbon flux in the Barents Sea. Progr. Oceanogr. 71, 232-287. doi: 10.1016/j.pocean.2006.10.003

Werner, I., and Auel, H. (2005). Seasonal variability in abundance, respiration and lipid composition of Arctic under-ice amphipods. Mar. Ecol. Prog. Ser. 292, 251-262. doi: 10.3354/meps292251

Werner, I., Auel, H., Garrity, C., and Hagen, W. (1999). Pelagic occurrence of the sympagic amphipod Gammarus wilkitzkii in ice-free waters of the Greenland Sea-dead end or part of life-cycle. Polar Biol. 22, 56-60. doi: 10.1007/ s003000050390

Woodgate, R. A., Aagaard, K., and Weingartner, T. J. (2005). A year in the physical oceanography of the Chukchi Sea: moored measurements from autumn 19901991. Deep Sea Res. Part II 52, 3116-3149. doi: 10.1016/j.dsr2.2005.10.016

Zenkevich, L. A. (1963). Biology of the Seas of the U.S.S.R. New York, NY: Interscience Publishers.

Conflict of Interest: The authors declare that the research was conducted in the absence of any commercial or financial relationships that could be construed as a potential conflict of interest.

Publisher's Note: All claims expressed in this article are solely those of the authors and do not necessarily represent those of their affiliated organizations, or those of the publisher, the editors and the reviewers. Any product that may be evaluated in this article, or claim that may be made by its manufacturer, is not guaranteed or endorsed by the publisher.

Copyright $\odot 2021$ Drivdal, Kunisch, Bluhm, Gradinger, Falk-Petersen and Berge. This is an open-access article distributed under the terms of the Creative Commons Attribution License (CC BY). The use, distribution or reproduction in other forums is permitted, provided the original author(s) and the copyright owner(s) are credited and that the original publication in this journal is cited, in accordance with accepted academic practice. No use, distribution or reproduction is permitted which does not comply with these terms. 